\title{
Lilah Grace Canevaro, Donncha O'Rourke (eds.), Didactic Poetry of Greece, Rome and Beyond: Knowledge, Power, Tradition, The Classical Press of Wales, Swansea 2019, 307 pp.; ISBN 978-1-910589-79-3
}

In recent years there has been a considerable increase of interest in ancient erudite, didactic and technical literature as a rightful part of belles-lettres, not just striving to teach the reader but also participating in the broadly defined cultural discourse. This is also the nature of the reviewed work, edited by Lilah Grace Canevaro (author of Hesiod's Works and Days: How to Teach Self-Sufficiency, Oxford University Press 2015 and Women of Substance in Homeric Epic: Objects, Gender, Agency, Oxford University Press 2018) and Donncha O'Rourke (who studies Roman poetry of the Late Republic and the Early Empire; his monograph Propertius and the Virgilian Sensibility is in press).

The authors of the collection aimed not to study didactic poetry as a separate literary genre, but to look at didacticism as a complex phenomenon permeating various forms of literary production, targeted at various readers and resultant from different expectations which impacted both the creation and reception of a given work. As the editors write,

Didactic texts do not operate in vacuum, but rather place expectations on an audience or reader ... didactic dynamics are manipulated through the persona or voice of the teacher, and are sometimes embedded in the poetry through the modelling of anticipated or ideal audiences. Furthermore, poet and reader are often joined by another authority such as the emperor, the king or other laudandus, creating a wider web of power that raises questions about where authority can legitimately - and safely - lie, and to what extent political power and power contingent on didactic knowledge overlap (p. 8).

Didactic poetry assumes different and sometimes surprising forms in this work, which follows from the mentioned focus of the authors of the articles included in it on the message of individual texts and their connection to didactic tradition rather than on form. For this reason, the discussed works include not only poems by Hesiod, Nicander of Colophon and Ovid as the author of Ars amatoria, but also Homeric epics and the Sibylline oracles. It must be admitted that this is a novel and very inspiring approach.

The collection consists of the "Introduction," written by the editors (pp. 1-20), and ten articles divided into three parts: (I) "Theory," (II) "Tracing Tradition" and (III) "Comparisons and Continuations." The first text included in the first part, written by Donncha O'Rourke ("Knowledge is Power: Dynamics of (Dis)empowerment in Didactic Poetry," pp. 21-52) is a good introduction to the following articles as well as an interesting application of Michel Foucault's thought on the relationship between knowledge and power, adapting it for didactic literature, which the author-and generally the 
entire volume - treats diachronically. The next article, written by Lilah Grace Canevaro ("Thinking for Yourself: Hesiod's 'Works and Days' and Cognitive Training," pp. 5374), is unfortunately much more difficult to read for a classical philologist (even though O'Rourke's article was also closer to contemporary philosophy than primary source exploration). In her article, Canevaro, using Warren Brown's definition of knowledge as an ability to solve problems in the face of their complexity, sophistication, novelty and/or unexpectedness, attempts to show that Hesiod in his work was very close to the contemporary theoretical reflection, but the way she does it is as if the ancient poet was familiar with this reflection. As a result, the article frequently uses anachronic statements such as "Hesiod is interested not only in the relative cognitive biases and abilities of the sexes, but also in those of different age groups" (p. 56). Canevaro's deep knowledge of contemporary cognitive science as well as her easily noticeable familiarity with Hesiod's oeuvre are certainly impressive, but her text seems to be addressed exclusively to those Hesiod specialists who are at the same time well acquainted with the philosophical and psychological theories referred to the article. One can also sometimes have the impression that the methodology adopted by the author seems to impose an interpretation of the discussed work according to a key chosen in advance, and it is the theory that should be constructed on the basis of analysing the sources, not the other way around.

The articles included in the second part of the reviewed work were written in a much more approachable language. Much easier to read are also the subject matter they discuss and the aim of their authors, who placed the studied primary texts in the centre of their attention. David Sider ("Homer Ethicus," pp. 75-95), referring to opinions expressed already by ancient readers of Homer (Xenophanes and Anaxagoras) argues that the author of Iliad and Odyssey was also not a stranger to the didactic wish to shape the behaviours of recipients of his works. The next text, by Floris Overduin ("Elegiac Pharmacology: The Didactic Heirs of Nicander?," pp. 97-122), which in my opinion is the most interesting one in the collection, is an analytic overview of poetic pharmacological texts written in the Late Hellenistic Period and the Early Empire. Overduin successfully tries to find out the reason behind choosing this specific form to convey seemingly hermetic knowledge, and what aims the authors of such texts had, apart from simply teaching their readers. Showing the intertextual depth of rarely studied and at present unpopular works is certainly a great value of this article. Particularly inspiring to other scholars, including historians, can also be Overduin's observations about connections between the didactic, cultural and political message of the analysed texts, which were, after all, addressed to the intellectual elite, including the emperor, and alluded to topics far exceeding the framework of pure didactics.

Monica R. Gale's text ("Name Puns and Acrostics in Didactic Poetry: Reading the Universe," pp. 123-150) is a cross-cutting approach to the subject of word games in didactic poetry (in particular acrostics and etymological paronomasias). Unlike many other scholars who treat them as a form of play, Gale notes their close relation to the didactic nature of the works themselves and to the desire to enter a dialogue with the older authors and to influence the reader-student. The last article in the second part of the collection, written by Elena Giusti ("Ovid's 'Ars poetica': Metapoetic Didactic in the 'Ars Amatoria'," pp. 151-177) is, in line with its title, an interesting attempt to appreciate Ovid as an attentive reader of Horace and a theoretician of didactic poetry-in this 
case not only a teacher of love but also a teacher of love poetry. Giusti's text can also be read as a valuable voice in the discussion on the arbitrariness of genre boundaries, selfawareness and intertextuality of Augustan poetry.

The third part of the reviewed collection consists of four very different articles devoted to less obvious (for various reasons) poetic texts belonging to the tradition of wisdom literature (Helen Van Noorden, "Didactic and Apocalyptic Turns: Clarity and Obscurity, Homer and Hesiod in the 'Sibylline Oracles'," pp. 179-204; Johannes Haubold, "Embodied Teaching, 'Ludlul Bēl Nēmeqi' and the Babylonian Didactic Tradition," pp. 205-224; Madhlozi Moyo, "Fauna and Erotic Didactics in Archaic Greek and Kalanga Oral Wisdom Literatures," pp. 225-248; David McOmish, "Scientia Demands the Latin Muse: The Authority of Didactic Poetry in Early-modern Scotland," pp. 249-274). The wide chronological, geographic and even cultural range of the discussed texts is conspicuous, which was undoubtedly deliberate and supposed to draw additional attention to the problem-based and diachronic approach of the authors towards the studied issue. All four texts, it must be said, are interesting and paradoxically a good fit with the other ones, even though Madhlozi Moyo's text can be criticised for the methodologically suspect move of comparing two traditions which are in no way-either temporarily or spatially - connected to each other. Searching for ethnographic analogies between Hesiod's oeuvre and the modern oral tradition from the territory of contemporary Zimbabwe is undoubtedly an interesting idea, but one should be aware of the risk involved in taking such a step. After all, the similarity between Hesiod's works and the folk wisdom of the Kalanga people can be entirely superficial and coincidental. It was certainly not the intention of the authors of the volume to show that in various parts of the world humans created wisdom literatures. In this context, I do not entirely see what the authors meant by stating in the introduction that the issues addressed in the volume are representative ("Introduction," p. 9).

There is no doubt that the applied key of text selection and the authors' research approach are fresh and worthwhile, and some of the texts can successfully be read separately as a valuable and inspiring voice in scholarly discussion, not only in the context of studies on didactic poetry. However, the strong psychological and philosophical leanings of the editors, whose texts precede the other articles and therefore in a way determine the reception of the entire publication, do make the whole work very difficult to receive and targeted mainly at specialists with theoretical inclinations.

Bartosz Jan Kołoczek http:/orcid.org/0000-0003-1401-0093 Jagiellonian University in Kraków 